\title{
Monomers Used in Resin Composites: Degree of Conversion, Mechanical Properties and Water Sorption/Solubility
}

\author{
Vinícius E. S. GAJEWSKI ${ }^{1}$ \\ Carmem S. PFEIFER ${ }^{2}$ \\ Nívea R. G. FRÓES-SALGADO ${ }^{1}$ \\ Letícia C. C. BOARO ${ }^{1}$ \\ Roberto R. BRAGA ${ }^{1}$
}

\begin{abstract}
${ }^{1}$ Department of Biomaterials and Oral Biology, Dental School, USP - University of São Paulo São Paulo, SP, Brazil ${ }^{2}$ Oregon Health and Science University, Department of Restorative Dentistry, Division of Biomaterials and Biomechanics, Portland, OR, USA
\end{abstract}

\begin{abstract}
The organic phase of resin composites is constituted by dimethacrylate resins, the most common monomers being the bisphenol A diglycidildimethacrylate (BisGMA), its ethoxylated version (BisEMA), triethylene glycol dimethacrylate (TEGDMA) and urethane dimethacrylate (UDMA). This study compared the homopolymers formed from the monomers used in restorative dental composites in terms of their degree of conversion (DC) and reaction kinetics (by near infra-red spectroscopy, n=3), mechanical properties (flexural modulus and strength in three point-bending, FM and FS, respectively, $\mathrm{n}=15$ ), water sorption and solubility (WS and SL, respectively - ISO 4049, n=5). Materials were made photopolymerizable by the addition of camphoroquinone/dimethylamine ethyl methacrylate. TEGDMA showed the highest DC, followed by BisEMA, UDMA and BisGMA, both at 10 min and at $24 \mathrm{~h}$ ( $\mathrm{p}<0.001$ ). UDMA showed the highest rate of polymerization, followed by TEGDMA, BisEMA and BisGMA $\left(\mathrm{H}_{0}=13.254, \mathrm{p}<0.001\right)$. UDMA and TEGDMA presented similar FM, significantly higher $(\mathrm{p}<0.001)$ than BisEMA and BisGMA, which in turn present statistically similar values $(\mathrm{p}>0.001)$. For FS, UDMA presented the highest value $(\mathrm{p}<0.001)$, followed by TEGDMA, then by BisEMA and BisGMA, which were statistically similar ( $p>0.001)$. BisGMA showed the highest WS, and TEGDMA and BisEMA the lowest. UDMA was statistically similar to all $\left(\mathrm{H}_{0}=16.074, \mathrm{p}<0.001\right)$. TEGDMA presented the highest SL, followed by UDMA, BisGMA and BisEMA $(\mathrm{p}<0.001)$. The tested homopolymers presented different behaviors in terms of polymerization kinetics, flexural properties, water sorption and solubility. Therefore, the use of copolymers is justified in order to obtain high DC and mechanical properties, as well as good resistance to water degradation.
\end{abstract}

Key Words: dimethacrylates, dental materials, polymerization, degree of conversion, mechanical properties.

\section{INTRODUCTION}

Dimethacrylate-based resins find many applications in restorative dentistry. They are used as adhesives, pit-and-fissure sealants, and can be combined with silane-coated glass fillers to render the most widely used esthetic direct restorative material, as well as cementation agents and veneering materials. Since their introduction to the market, for over half a century the research effort has focused on improving the formulations that use these monomers to increase their clinical service.
Dimethacrylate copolymerization through light or heat activation in the presence of an initiator results in a crosslinked polymer whose physicochemical properties depend on the degree of conversion (DC) and final network structure (1). The base monomer most widely used commercially is BisGMA (bisphenol A diglycidil dimethacrylate; $M W=512$ g/mol; Fig. 1). Despite its high intrinsic reactivity, the presence of hydroxyl groups on the backbone and the $\pi-\pi$ interactions given by the aromatic rings increase the initial viscosity $(\eta=1,200 \mathrm{~Pa})$ to a point that the homopolymer typically does not reach high conversion. For that reason, and also to improve 
handling characteristics and allow incorporation of higher inorganic filler contents, BisGMA is usually combined with low viscosity monomers like TEGDMA(triethylene glycol dimethacrylate; $\mathrm{MW}=286 \mathrm{~g} / \mathrm{mol}, \eta=0.01 \mathrm{~Pa}$; Fig. 1) (2). However, addition of TEGDMA increases water sorption (3), decreases general mechanical properties (4) and hinders color stability (5).

Other high molecular weight monomers have since been developed and introduced in commercial materials to overcome the limitations of BisGMAbased systems. As an example, formulations based on urethane dimethacrylate (UDMA; $\mathrm{MW}=470 \mathrm{~g} / \mathrm{mol} ; \eta=23$ Pa; Fig. 1) became increasingly common, due to this monomer's low viscosity and high flexibility in relation to BisGMA (6). UDMA copolymers in general present higher flexural strength, elastic modulus and hardness (7). Another alternative is the ethoxylated version of BisGMA, known as BisEMA (ethoxylatedbisphenol A dimethacrylate; $\eta=0.9$ Pa; Fig. 1) with higher molecular weight (MW=540 $\mathrm{g} / \mathrm{mol}$ ), however without the strong secondary molecular interactions given by hydroxyl groups, which reduces its viscosity and allows for higher DC and better mechanical properties to be achieved (8).

When exposed to oral fluids, these materials might suffer hydrolysis with consequent leaching of unreacted monomers or even low molecular weight oligomers (9). Also, the filler bonding agent can also degrade (10). All these factors together cause material degradation, with significant decrease of mechanical properties, ultimately leading to restoration failure (11).

Although homopolymers are not used commercially, understanding their basic individual properties contributes to the design of more efficient copolymer formulations. While their general properties have been described in the past, in studies on experimental monomers that included them as controls $(6,12,13)$, a systematic evaluation of the most commonly used monomers in dental restorations, evaluated under the same experimental conditions, is still lacking. This study compares the homopolymers used in restorative dental composites in terms of their DC, reaction kinetics, mechanical properties (flexural modulus and strength), water sorption and solubility.

\section{MATERIAL AND METHODS}

\section{Materials}

Monomers (Table 1) were used as received, with no further purification. Materials were made photopolymerizable by adding the photosensitizer camphoroquinone and the primary amine dimethylamine ethyl methacrylate (DMAEMA), at 0.4 and $0.8 \mathrm{~mol} \%$, respectively. BisGMA was briefly heated to $50^{\circ} \mathrm{C}$ to decrease viscosity and allow the incorporation of the initiators. Materials were stored in the dark under refrigeration at $5 \pm 2^{\circ} \mathrm{C}$ for $24 \mathrm{~h}$, then left on the bench top at room temperature $\left(22 \pm 2^{\circ} \mathrm{C}\right)$ for $2 \mathrm{~h}$ prior to use.

\section{Fourier Transformed Near-Infrared (NIR) Spectroscopy}

DC and maximum rate of polymerization were obtained through Fourier transformed near-infrared (NIR) spectroscopy $(\mathrm{n}=3)$ (Vertex 70; Bruker Co., Ettlingen, Germany) at $22 \pm 2^{\circ} \mathrm{C}$. Cylindrical specimens $(0.8 \mathrm{~mm}$ thick and $8 \mathrm{~mm}$ in diameter) were constructed in polydimethylsiloxane molds (Rapid System Pack; Coltène/Whaledent, Altstätten, Switzerland), filled with the resin and sandwiched between glass slides. Spectra were acquired at $4 \mathrm{~cm}^{-1}$ with $2 \mathrm{scans} / \mathrm{s}$. The first four spectra were used to obtain the areas under the methacrylate first overtone peak $\left(6,165 \mathrm{~cm}^{-1}\right)$ in the monomeric state, then polymerization (accomplished with a $20 \mathrm{~s}$ illumination at, according to manufacturer's information, approximately $1,100 \mathrm{~mW} / \mathrm{cm}^{2}$ by Flash Lite 1401, Discus Dental Co., Culver City, CA, USA) was followed for $10 \mathrm{~min}$ (Opus v6, Bruker). Conversion (DC, in $\%$ ) in real time was calculated as follows:

$D C=\left(1-\frac{p o l}{n p o l}\right) \times 100$
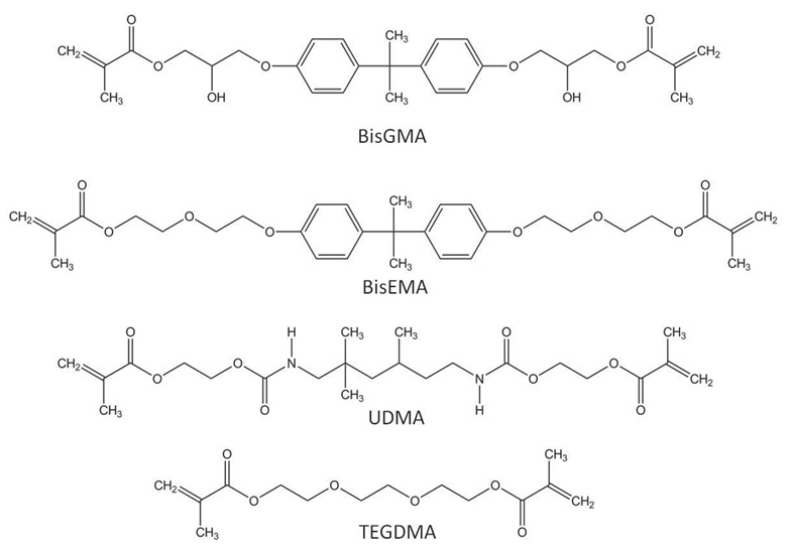

Figure 1. Molecular structures of monomers. 
Where pol and npol correspond to the area of the methacrylate peak for the polymeric and monomeric states, respectively. Maximum rate of polymerization $\left(\mathrm{Rp}_{\max }\right)$ was calculated as the first derivative of the DC $\mathrm{x}$ time curve. Specimens were stored dry at $37^{\circ} \mathrm{C}$ for 24 $\mathrm{h}$ and a new conversion measurement was taken.

\section{Flexural Strength and Modulus of Elasticity}

Bar-shaped specimens $(10 \times 2 \times 1 \mathrm{~mm}, \mathrm{n}=15)$ were made using polydimethylsiloxane (Rapid System Pack, Coltène/Whaledent) molds. The material was polymerized on one of the sides for $40 \mathrm{~s}$ at $600 \mathrm{~mW} /$ $\mathrm{cm}^{2}$ with a quartz-tungsten-halogen light source (VIP Jr.; Bisco Inc., Schaumburg, IL, USA). Irradiance was checked daily with a dental radiometer (100; Kerr Co., Orange, CA, USA). After photoactivation, specimens were measured to the second decimal place (IP67; Mitutoyo, São Paulo, SP, Brazil) and stored dry at 37 $\pm 2{ }^{\circ} \mathrm{C}$ for $24 \mathrm{~h}$ until being tested in a universal testing machine (K200MP; Kratos, Cotia, SP, Brazil) in a threepoint bending design (span between supports of $6.0 \mathrm{~mm}$; crosshead speed of $0.5 \mathrm{~mm} / \mathrm{s}$ ) until failure.

Flexural modulus (FM - GPa) and flexural strength (FS - MPa) were calculated using the following equations:
$\mathrm{FS}=\frac{3 \times \mathrm{L} \times \mathrm{D}}{2 \times w \times \mathrm{h}^{2}}$

$E=\frac{L x D^{3}}{4 x w h^{3} x d}$

Where: $L(\mathrm{~N})$ is the load recorded in the elastic portion, $D(\mathrm{~mm})$ is the distance between supports, $w(\mathrm{~mm})$ is the width of the sample, $d(\mathrm{~mm})$ is the displacement of the beam corresponding to $\mathrm{L}$, and $\mathrm{h}$ $(\mathrm{mm})$ thickness of the sample.

\section{Water Sorption and Solubility}

Water sorption and solubility were obtained according to ISO 4049 (14). Specimens with $15 \mathrm{~mm}$ in diameter and $1 \mathrm{~mm}$ thick $(\mathrm{n}=5)$ were made in a steel split mold. Resins were sandwiched in the mold between glass slides and photoactivated (Flash Lite 1401) on each side with 5 overlapping exposures, for $15 \mathrm{~s}$ each (75 $\mathrm{s}$ total). The initial mass $\left(\mathrm{m}_{0}\right)$ was recorded to the $0.01 \mathrm{mg}$ (XS 105; Mettler-Toledo, Toledo, OH, USA). Initial dimensions (thickness $-\mathrm{e}_{0}$, and diameter $-\mathrm{d}_{0}$ ) were also recorded for the calculation of the volume of

Table 1. Monomers and photoinitiators used in this study.

\begin{tabular}{|c|c|c|c|c|c|c|}
\hline & $\begin{array}{c}\text { Chemical } \\
\text { nomenclature (IUPAC) }\end{array}$ & $\begin{array}{c}\text { Molecular } \\
\text { weight }(\mathrm{g} / \mathrm{mol})\end{array}$ & $\begin{array}{l}\text { Molecular } \\
\text { Formula }\end{array}$ & $\begin{array}{l}\text { Viscosity } \\
(\mathrm{h}-\mathrm{Pa})\end{array}$ & Manufacturer & Batch \# \\
\hline BisGMA & $\begin{array}{l}\text { 2,2-bis-4-2-(hydroxi-3- } \\
\text { metacriloxiprop-1-oxi)propane }\end{array}$ & 512 & $\mathrm{C}_{29} \mathrm{H}_{36} \mathrm{O}_{8}$ & 1200 & $\begin{array}{l}\text { Esstech Inc., } \\
\text { Essington, PA, } \\
\text { USA }\end{array}$ & $568-21-07$ \\
\hline TEGDMA & Triethylene glycol dimethacrylate & 286 & $\mathrm{C}_{14} \mathrm{H}_{22} \mathrm{O}_{6}$ & 0.01 & $\begin{array}{l}\text { Esstech Inc., } \\
\text { Essington, PA, } \\
\text { USA }\end{array}$ & $562-07-04$ \\
\hline UDMA & $\begin{array}{l}\text { 1,6-bis-(metalocriloxi-2- } \\
\text { etoxicarbolamino)-2,4,4- } \\
\text { trimethylexane }\end{array}$ & 470 & $\mathrm{C}_{23} \mathrm{H}_{38} \mathrm{~N}_{2} \mathrm{O}_{8}$ & 23 & $\begin{array}{l}\text { Sigma-Aldrich } \\
\text { Inc., St. Louis, } \\
\text { MO, USA }\end{array}$ & 06324EC \\
\hline BisEMA & $\begin{array}{l}\text { 2,2-bis-4-2-(hydroxi-3- } \\
\text { methylacriloxietoxi)-phenylpropane }\end{array}$ & 540 & $\mathrm{C}_{39} \mathrm{H}_{44} \mathrm{O}_{8}$ & 0.9 & $\begin{array}{l}\text { Sigma-Aldrich } \\
\text { Inc., St. Louis, } \\
\text { MO, USA }\end{array}$ & $03514 \mathrm{HF}$ \\
\hline Camphorquinone & 2,3-bornadenione & 166 & $\mathrm{C}_{10} \mathrm{H}_{14} \mathrm{O}_{2}$ & N/A & $\begin{array}{l}\text { Sigma-Aldrich } \\
\text { Inc., St. Louis, } \\
\text { MO, USA }\end{array}$ & $51602-065$ \\
\hline DMAEMA & $\begin{array}{l}\text { 2-(dimethylamino)ethyl } \\
\text { methacrylate }\end{array}$ & 157 & $\mathrm{C}_{7} \mathrm{H}_{14} \mathrm{NO}_{2}$ & 0.9 & $\begin{array}{l}\text { Sigma-Aldrich } \\
\text { Inc., St. Louis, } \\
\text { MO, USA }\end{array}$ & $08328 \mathrm{HC}$ \\
\hline
\end{tabular}


the specimen $\left(\mathrm{V}_{0}\right)$, according to the equation:

$V=\pi x\left(\frac{d}{2}\right)^{2} x e^{2}$

Specimens were stored in a desiccator avoiding contact with the wall of the container under vacuum, at $37 \pm 2{ }^{\circ} \mathrm{C}$ until a stable mass reading was obtained $\left(\mathrm{m}_{1}\right)$. Only then were the specimens transferred to vials containing $10 \mathrm{~mL}$ of distilled water, where they were stored for 7 days at $37 \pm 2^{\circ} \mathrm{C}$ to obtain $\mathrm{m}_{2}$. Specimens were then stored in a desiccator under vacuum at $37 \pm$ $2^{\circ} \mathrm{C}$ until a second stable mass reading was obtained $\left(\mathrm{m}_{3}\right)$, which took approximately 30 days. Water sorption(WS $-\mu \mathrm{g} / \mathrm{mm}^{3}$ ) and solubility $\left(\mathrm{SL}-\mu \mathrm{g} / \mathrm{mm}^{3}\right)$ were calculated according to the equations:

$W S=\frac{m_{\mathrm{a}}-m_{\mathrm{a}}}{V_{\mathrm{n}}}$
$S L=\frac{m_{1}-m_{\mathrm{a}}}{V_{0}}$

\section{Statistical Analysis}

Data for E, FS, SL and DC were analyzed with one-way ANOVA and Tukey's test. WS and $\mathrm{Rp}_{\max }$ data were not homocedastic, thus Kruskal-Wallis analysis was performed. The global significance level was set at $95 \%$.

\section{RESULTS}

Results are presented in Table 2 and Figure 2. TEGDMA showed the highest DC, followed by
BisEMA, UDMA and BisGMA, both at 10 min and at 24 $\mathrm{h}(\mathrm{p}<0.001)$. UDMA showed the highest $\mathrm{Rp}_{\max }$, followed by TEGDMA, BisEMA and BisGMA $\left(\mathrm{H}_{0}=13.254\right.$, $\mathrm{p}=0.001$ ).

UDMA and TEGDMA presented similar modulus of elasticity values, significantly higher than those of BisEMA and BisGMA $(p<0.001)$, which in turn present statistically similar values $(p>0.001)$. For FS, UDMA presented the highest value, followed by TEGDMA, then by BisEMA and BisGMA $(\mathrm{p}<0.001)$, which in turn were statistically similar $(p>0.001)$.

BisGMA showed the highest WS, and TEGDMA and BisEMA the lowest $(\mathrm{p}<0.001)$. UDMA was statistically similar to all monomers $\left(\mathrm{H}_{0}=16.074\right.$, $\mathrm{p}=0.001$ ). TEGDMA presented the highest SL, followed by UDMA, BisGMA and BisEMA $(\mathrm{p}<0.001)$.

\section{DISCUSSION}

TEGDMA is a highly flexible, low-molecularweight, low-viscosity monomer, all characteristics that contribute to high mobility during polymerization, and consequently favoring conversion (15). The tendency to cyclization also leads to higher conversion, but not necessarily contributes to network formation (16). The absence of strong secondary intermolecular interactions (such as hydrogen bonding) helps explaining the low viscosity and high mobility, and can also be used to justify the three-fold increase in conversion presented by BisEMA in relation to BisGMA, two analog molecules, with only the hydrogen bonding ability as a structural difference $(17,18)$. In the specific case of the BisEMA monomer used in this study, the ethylene glycol spacer

Table 2. Means and standard deviations for degree of conversion (DC), maximum rate of polymerization (Rpmax), flexural strength (FS), modulus of elasticity (E), water sorption (WS) and solubility (SL) of dimethacrylate homopolymers.

\begin{tabular}{|c|c|c|c|c|c|c|c|c|}
\hline Monomer & $\begin{array}{c}\text { DC@10 min } \\
(\%)\end{array}$ & $\begin{array}{c}\text { DC@24h } \\
(\%)\end{array}$ & $\begin{array}{c}\mathrm{DC} @ \mathrm{Rp}_{\max } \\
(\%)\end{array}$ & $\begin{array}{l}\mathrm{Rp}_{\max } \\
\left(\% . \mathrm{s}^{-1}\right)\end{array}$ & $\begin{array}{c}\mathrm{FS} \\
(\mathrm{MPa})\end{array}$ & $\begin{array}{c}\mathrm{E} \\
(\mathrm{GPa})\end{array}$ & $\begin{array}{c}\text { WS } \\
\left(\mu \mathrm{g} / \mathrm{mm}^{3}\right)\end{array}$ & $\begin{array}{c}\mathrm{SL} \\
\left(\mu \mathrm{g} / \mathrm{mm}^{3}\right)\end{array}$ \\
\hline BisGMA & $21.7(2.7)^{d}$ & $34.5(1.4)^{d}$ & $5.9(0.7)^{\mathrm{c}}$ & $\begin{array}{c}0.78(0.20) \\
\mathrm{d}\end{array}$ & $72.4(13.6)^{\mathrm{c}}$ & $1.0(0.2)^{b}$ & $51.2(8.5)^{\mathrm{a}}$ & $9.5(1.7)^{\mathrm{c}}$ \\
\hline TEGDMA & $74.0(2.2)^{\mathrm{a}}$ & $82.5(0.8)^{a}$ & $47.6(0.9)^{\mathrm{a}}$ & $\begin{array}{c}3.69(0.24) \\
\mathrm{b}\end{array}$ & $99.1(22.8)^{b}$ & $1.7(0.3)^{\mathrm{a}}$ & $28.8(3.7)^{b}$ & $27.5(3.7)^{\mathrm{a}}$ \\
\hline UDMA & $59.6(1.7)^{\mathrm{c}}$ & $72.4(0.4)^{\mathrm{c}}$ & $15.6(0.3)^{b}$ & $\begin{array}{c}8.26(1.65) \\
\mathrm{a}\end{array}$ & $133.8(21.9)^{\mathrm{a}}$ & $1.8(0.5)^{\mathrm{a}}$ & $42.3(0.8)^{a b}$ & $20.4(2.7)^{b}$ \\
\hline BisEMA & $65.5(1.2)^{b}$ & $75.5(0.4)^{b}$ & $7.4(0.2)^{\mathrm{c}}$ & $\begin{array}{c}2.25(0.20) \\
\mathrm{c}\end{array}$ & $87.3(16.5)^{c}$ & $1.1(0.3)^{b}$ & $21.3(0.8)^{b}$ & $2.1(0.8)^{d}$ \\
\hline
\end{tabular}

For a given test, values followed by the same superscript letter in the same column are not statistically different $(\mathrm{p}<0.05)$. 
is also longer compared to the one present in BisGMA, which adds to its flexibility and also explains the significant differences in conversion between the two. UDMA allies a very flexible backbone with weaker hydrogen bonding given by the urethane groups (4), and that explains why the conversion values were, although statistically different, fairly close to the ones obtained by BisEMA. BisGMA is a very hindered molecule, both due to the presence of strong hydrogen bonding interactions (17) and $\pi-\pi$ interactions given by the bisphenol A core (19), which also results in very low flexibility. This hinders initial mobility and leads to gelation at low conversions, ultimately leading to low overall conversion values (19). Evidence for that is the very low conversion at which the maximum rate of polymerization is observed for BisGMA $(5.9 \%)$ and its ethoxylated analog (BisEMA, at 7.4\%). For these two monomers, this means that the reaction became diffusion controlled at earlier stages of conversion, regardless of the hydrogen bonding potential. As network development progressed, vitrification (given by the conversion at deceleration) (19), occurred much earlier in conversion for BisGMA than for BisEMA(Fig. 2 ), showing that the lack of secondary intermolecular interactions played a more significant role at the later stages of network development. As for the more flexible TEGDMA and UDMA, though the comparison is not as direct as the one made between BisGMA and BisEMA (which are exact analogs with different hydrogen bonding potential), deceleration also occurred later for the less hydrophilic TEGDMA (at $47.6 \%$, as opposed to $15.6 \%$ for UDMA). In that case, the three-fold increase

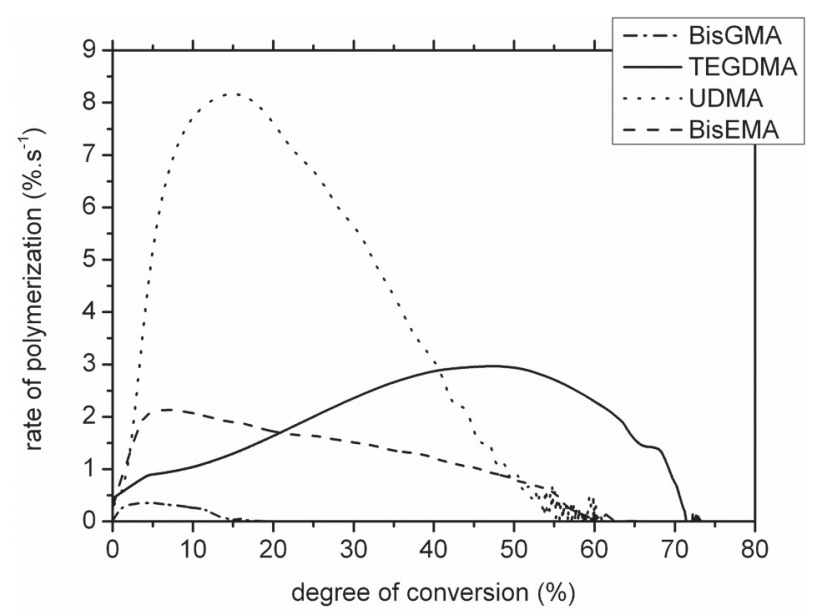

Figure 2. Polymerization rate as a function of degree of conversion for the tested materials. in conversion at $\mathrm{Rp}_{\max }$ and the later deceleration for TEGDMA are explained both by the lesser hydrogen bonding potential and by the greater cyclization, which contributes to conversion (the highest one in the study), but not network formation, as previously mentioned.

For all monomers, conversion after $24 \mathrm{~h}$ storage increased by approximately $10 \%$ (Table 2), in spite of the much greater amount of entrapped radicals expected to be found in the material with lowest conversion at 10 $\min$ (BisGMA). Assuming that the radical efficiency was the same for all materials (which is reasonable since the initiator concentration and irradiance were the same for all of them) (20), this highlights the effects of mobility restrictions imposed by the very viscous BisGMA monomer (1,200 Pa.s) to network formation. All these explain why the maximum polymerization rate does not correlate linearly with the final values of conversion (21).

Mechanical properties are a function of the DC and the three-dimensional structure of the polymer network $(1,18)$. For the polymers tested in this study, the lowest FS and E were observed for BisGMA, in spite of the very strong intermolecular interactions and the rigid backbone, due to the very low DC achieved. Among the other three monomers, the highest FS and E were presented by UDMA, in spite of the lowest conversion, probably due to a combination of stronger hydrogen bonding potential (17), shorter crosslinks (in relation to BisEMA) (21) that are expected to render less free volume (22) and less cyclization (in relation to TEGDMA) (23). Owing to these interactions and the consequences to water sorption and solubility (discussed in the following paragraphs), these dimethacrylates have been successfully combined in dental composites formulations (24).

In general terms, water sorption correlates with the conversion achieved by the polymer and also with the nature of the formed network, both in terms of its relative hydrophilicity, and the tridimensional structure and free volume (22). In this study, WS increased with the decrease in conversion in the tested formulations, as expected. BisEMA showed the lowest WS, both due to the relatively high conversion and to the hydrophobic character of the molecule (17). In the case of TEGDMA, the high conversion does not necessarily translate into high crosslinking density, as previously mentioned, so the second to last lowest WS was somewhat surprising (25) and must be correlated with its lower hydrophilicity compared with BisGMA and UDMA. BisGMA and UDMA showed very similar WS values, in spite of 
the differences in conversion, probably because those two are the most hydrophilic molecules evaluated in this study.

The SL results depend not only on the amount of water absorbed into the network, but also on the amount and hydrophilic character of the leachables present in the product. In addition, pendant double bonds that contribute to greater free volume to the network (22) and favor water sorption, might not contribute to leachable species (monomers and oligomers), since they are tied to the network. This explains why the SL values for BisGMA were not the greatest among the homopolymers, in spite of its significantly higher WS. TEGDMA, on the other hand, due to the tendency to cyclization, showed the highest solubility results, in spite of the highest conversion and low WS, probably because low-molecular-weight oligomers were present and ready to leach. The lowest solubility values from BisEMA are explained by both the relatively high conversion (in this case, probably also with greater crosslinking) and the hydrophobic character of the molecule. It also has to be pointed out that the solubility results might have been underestimated for the more hydrophilic monomers, since water yields strong hydrogen bonding interactions with the hydroxyl and urethane groups (in BisGMA and UDMA, respectively) and weaker bonds with the ethylene glycol units (present in a greater concentration in TEGDMA than in BisEMA), which may hinder water elimination during the second storage period in the desiccators (15).

The individual features of the tested dimethacrylate homopolymers appeared to be responsible for their distinctive behaviors in terms of polymerization kinetics, flexural properties, water sorption and solubility. Such characteristics justify the use of copolymers in order to obtain high DC and mechanical properties, as well as good resistance to water degradation.

\section{RESUMO}

A fase orgânica de compósitos resinosos é constituída por dimetacrilatos, sendo os mais comuns o dimetacrilato de diglicidilabisfenol A(BisGMA), sua versão etoxilada (BisEMA), dimetacrilato de trietilenoglicol (TEGDMA) e dimetacrilato de uretano (UDMA). Este estudo comparou os homopolímeros formados pelos monômeros utilizados em compósitos restauradores dentários em relação a seus graus de conversão (GC) e cinética de reação (através de espectroscopia no infra-vermelho), propriedades mecânicas (módulo de elasticidade em flexão e resistência à flexão, $\mathrm{MF}$ e RF, respectivamente), sorção de água e solubilidade (SA e SL, respectivamente - ISO4049). Os materiais se tornaram fotopolimerizáveis pela adição de canforoquinona/ metacrilato de dimetilaminoetila e foram fotoativados utilizando uma fonte de luz de quartzo-tungstênio-halogênio filtrada para 400-500 nm. O TEGDMA apresentou o maior GC, seguido pelo BisEMA, UDMA e BisGMA, tanto aos 10 min quanto após 24 $\mathrm{h}(\mathrm{p}<0,001)$. O UDMA mostrou a maior velocidade de reação, seguido pelo TEGDMA, BisEMA e BisGMA $\left(\mathrm{H}_{0}=13,254\right.$, $\mathrm{p}<0,001)$. OUDMA o TEGDMA apresentaram MF semelhantes, estatisticamente superiores ao BisEMA e ao $\operatorname{BisGMA}(p<0,001)$, os quais por sua vez apresentaram valores estatisticamente semelhantes $(p>0,001)$. Para RF, o UDMA apresentou o valor mais alto, seguido pelo TEGDMA, BisEMA e BisGMA $(p<0,001)$, sendo os dois últimos estatisticamente semelhantes ( $>0,001)$. O BisGMA apresentou a maior SA, e o TEGDMA e o BisEMA as menores. O UDMA foi estatisticamente semelhante a todos $\left(\mathrm{H}_{0}=16,074, \mathrm{p}<0,001\right)$. O TEGDMA apresentou a maior $\mathrm{SL}$, seguido pelo UDMA, BisGMA e BisEMA $(\mathrm{p}<0,001)$. Os homopolímeros demonstraram desempenhos bastante distintos em relação à cinética de polimerização, propriedades em flexão e sorção e solubilidade. Tais diferenças justificam o uso de copolímeros para a obtenção de materiais com propriedades físicas otimizadas.

\section{ACKNOWLEDGEMENTS}

Research funding provided by PIBIC/CNPq is greatly appreciated.

\section{REFERENCES}

1. Asmussen E, Peutzfeldt A. Influence of UEDMA BisGMA and TEGDMA on selected mechanical properties of experimental resin composites. Dent Mater 1998;14:51-56.

2. Peutzfeldt A. Resin composites in dentistry: the monomer systems. Eur J Oral Sci 1997;105:97-116.

3. Sideridou ID, Karabela MM, Bikiaris DN. Aging studies of light cured dimethacrylate-based dental resins and a resin composite in water or ethanol/water. Dent Mater 2007;23:1142-1149.

4. Goncalves F, Pfeifer CC, Stansbury JW, Newman SM, Braga RR. Influence of matrix composition on polymerization stress development of experimental composites. Dent Mater 2010; 26:697-703.

5. Janda R, Roulet JF, Latta M, Ruttermann S. Water sorption and solubility of contemporary resin-based filling materials. J Biomed Mater Res B Appl Biomater 2007;82:545-551.

6. Floyd CJ, Dickens SH. Network structure of Bis-GMA- and UDMA-based resin systems. Dent Mater 2006;22:1143-1149.

7. Tanimoto Y, Hayakawa T, Nemoto K. Analysis of photopolymerization behavior of UDMA/TEGDMA resin mixture and its composite by differential scanning calorimetry. J Biomed Mater Res B Appl Biomater 2005;72:310-315.

8. Ogliari FA, Ely C, Zanchi CH, Fortes CB, Samuel SM, Demarco $\mathrm{FF}$, et al.. Influence of chain extender length of aromatic dimethacrylates on polymer network development. Dent Mater 2008;24:165-171.

9. Van Landuyt KL, Nawrot T, Geebelen B, De Munck J, Snauwaert J, Yoshihara K, et al.. How much do resin-based dental materials release? A meta-analytical approach. Dent Mater 2011;27:723747.

10. Archegas LR, Caldas DB, Rached RN, Vieira S, Souza EM. Sorption and solubility of composites cured with quartz-tungsten halogen and light emitting diode light-curing units. J Contemp 
Dent Pract 2008;9:73-80.

11. Berger SB, Palialol AR, Cavalli V, Giannini M. Characterization of water sorption, solubility and filler particles of light-cured composite resins. Braz Dent J 2009;20:314-318.

12. Khatri CA, Stansbury JW, Schultheisz CR, Antonucci JM. Synthesis, characterization and evaluation of urethane derivatives of Bis-GMA. Dent Mater 2003;19:584-588.

13. Patel MP, Braden M, Davy KW. Polymerization shrinkage of methacrylate esters. Biomaterials 1987;8:53-56.

14. ASTM. ASTM D-790. 2011; DOI: 10.1520/D0790-10:

15. Sideridou I, Karabela MM, Vouvoudi E. Dynamic thermomechanical properties and sorption characteristics of two commercial light cured dental resin composites. Dent Mater 2008;24:737-743.

16. Lovell LG, Stansbury JW, Syrpes DC, Bowman CN. Effects of composition and reactivity on the reaction kinetics of dimethacrylate/dimethacrylate copolimerizations. Macromolecules 1999;32:3913-3921.

17. Lemon MT, Jones MS, Stansbury JW. Hydrogen bonding interactions in methacrylate monomers and polymers. J Biomed Mater Res A 2007;83A:734-746.

18. Stansbury JW. Synthesis, evaluation of novel multifunctional oligomers for dentistry. J Dent Res 1992;71:434-437.
19. Odian G. Principles of polymerization. $4^{\text {th }}$ ed. New York: WileyInterscience 2004.

20. Fouassier JP. Photoinitiation, Photopolymerization and Photocuring - Fundamentals and Applications. Cincinnati, OH: Hanser Gardner Publications Inc.; 1995.

21. Dickens SH, Stansbury JW, KM C, Floyd CJE. Photopolymerization kinetics of methacrylate dental resins. Macromolecules 2003;36:6046-6053.

22. Pfeifer CS, Shelton ZR, Braga RR, Windmoller D, Machado JC, Stansbury JW. Characterization of dimethacrylate polymeric networks: A study of the crosslinked structure formed by monomers used in dental composites. Eur Pol J 2011;47:162-170.

23. Anseth KS, Kline LM, Walker TA, Anderson KJ, Bowman CN. Reaction-kinetics and volume relaxation during polymerizations of multiethylene glycol dimethacrylates. Macromolecules 1995;28:2491-2499.

24. Rybarek IMB. Structure-property relationships in dimethacrylate networks based on Bis-GMA, UDMA and TEGDMA. Dent Mater 2009;25:1082-1089.

25. Sideridou I, Tserki V, Papanastasiou G. Study of water sorption, solubility and modulus of elasticity of light-cured dimethacrylatebased dental resins. Biomaterials 2003;24:655-665.

Received June 27, 2012 Accepted November 31, 2012 